\title{
Novel dinuclear platinum(II) complexes targets NFKB signaling pathway to induce apoptosis and inhibit metabolism of MCF-7 breast cancer cells
}

\author{
Bożena Popławska1, Anna Bielawska1, Arkadiusz Surażyński², Robert Czarnomysy ${ }^{3}$, \\ Krzysztof Bielawski ${ }^{3}$
}

${ }^{1}$ Department of Biotechnology, Medical University of Białystok, Białystok, Poland.

${ }^{2}$ Department of Medicinal Chemistry, Medical University of Białystok, Białystok, Poland

${ }^{3}$ Department of Synthesis and Technology of Drugs, Medical University of Białystok, Białystok, Poland

\begin{abstract}
Four novel dinuclear platinum(II) complexes of formula $\left[\mathrm{Pt}_{2} \mathrm{~L}_{4}\right.$ (berenil) $\left.{ }_{2}\right] \mathrm{Cl}_{4}(\mathrm{Pt} 1$-Pt4) where $\mathrm{L}$ is piperazine (Pt1), 4-picoline (Pt2), 3-picoline (Pt3) or isopropylamine (Pt4) were compared to cisplatin in respect to collagen biosynthesis, $\beta_{1}$ - integrin receptor, IGF-I receptor, phosphorylated MAP-kinases (ERK ${ }_{1} / E_{2} K_{2}$ and p38), phosphorylated Akt kinase expression and appearance of apoptosis in MCF-7 breast cancer cells. It was found that Pt1-Pt4 were more active inhibitor of collagen biosynthesis than cisplatin. The expression of IGF-I and $\beta_{1}$ integrin receptor, as well as phosphorylated MAPK, $\left(\right.$ ERK $_{1}$ and ERK 2 and p38) was significantly increased in cells incubated for $24 \mathrm{~h}$ with $20 \mu \mathrm{M}$ Pt1-Pt4 compared to the control, not treated cells. The phenomenon was related to the increase expresion of NFKB by Pt1-Pt4 as shown by Western immunoblot analysis. Experiments made with annexin V-FITC and detection of apoptosis by a fluorescent microscopy assay revealed that novel dinuclear platinum(II) complexes (Pt1-Pt4) inhibited the proliferation of MCF-7 breast cancer cells by increasing the number of apoptotic and necrotic cells.
\end{abstract}

Keywords: dinuclear platinum(II) complexes, breast cancer cells, collagen biosynthesis, IGF-I receptor, NFkB signaling, apoptosis

\section{Introduction}

Platinum compounds are among the most important chemotherapeutic agents for treatment of cancer and cisplatin has been the primary platinum based drug for cancer treatment [1-3]. Despite its success, the clinical usefulness of cisplatin is limited by its severe side effects such as dose-dependent nephrotoxicity, nausea and vomiting, ototoxicity, neurotoxicity, and myelosuppression [1-3]. The need for alternatives to cisplatin has consequently inspired further work towards the development of novel platinum-based drugs with improved and or complementary properties. Polynuclear platinum compounds comprise a unique class of anticancer platinum agents with distinct chemical and biological properties discrete from mononuclear platinum drugs $[4,5]$.

Correspondence: A. Bielawska, Dept. of Biotechnology,

Medical University of Białystok, Kilińskiego 1,

15-089 Bialystok, Poland; tel.: (+4885) 7485701,

fax.: (+4885) 7485416, e-mail: aniabiel@amb.edu.pl
The present study was undertaken to extend our recent findings related to antineoplastic activity of novel dinuclear platinum(II) complexes [6,7]. In this study, the effects of the compounds of formula $\left.\left[\mathrm{Pt}_{2} \mathrm{~L}_{4} \text { (berenil) }\right)_{2}\right] \mathrm{Cl}_{4}$ where $\mathrm{L}$ is piperazine $(\mathrm{Pt} 1)$, 4-picoline (Pt2), 3-picoline (Pt3) or isopropylamine (Pt4) (Fig. 1) on collagen biosynthesis, $\beta_{1}$-integrin receptor, IGF-I receptor and the expression of several proteins in the signal generated through these receptors like: phosphorylated MAP-kinases (ERK1/2 and p38), phospho-Akt, NFKB and appearance of apoptosis in MCF-7 breast cancer cells were compared to those evoked by cisplatin.

Collagen biosynthesis is regulated by the signal mediated by activated $\beta_{1}$-integrin receptors and IGF receptor [8]. Stimulated $\beta_{1}$-integrin receptors induce autophosphorylation of non-receptor focal adhesion kinase pp125 FAK (FAK) [9], which is then capable of interacting with adaptor-proteins, such as Grb2, through Src and Shc proteins. This interaction allows to activate further cascade of signaling pathway 


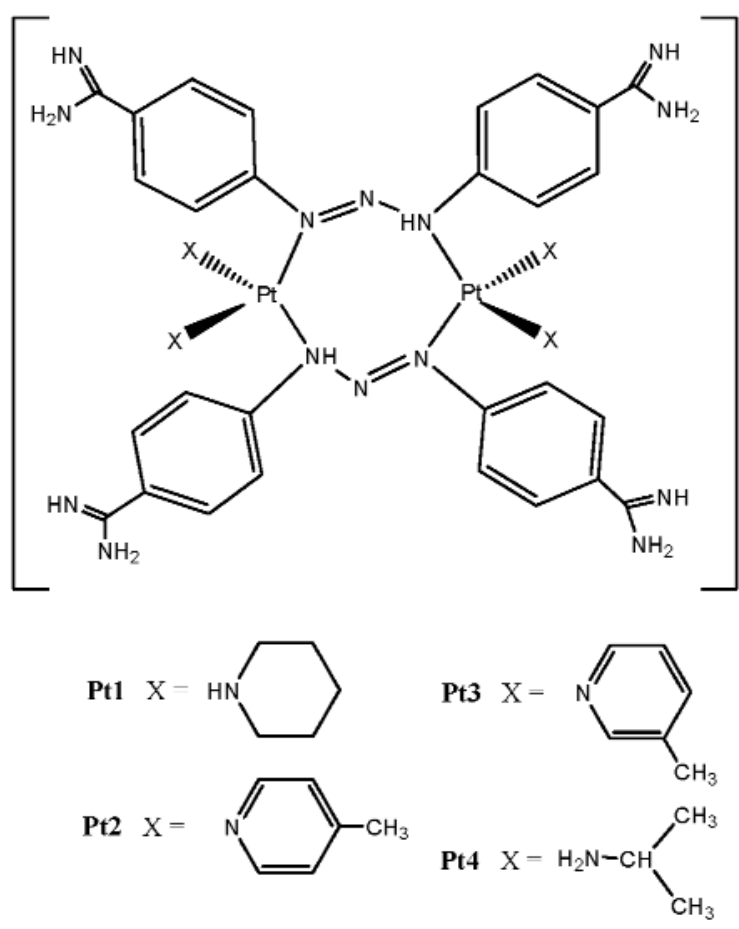

Fig. 1. Structure of compounds Pt1-Pt4.

through son of sevenless protein (Sos-1), Ras and Raf proteins [10] and subsequently, two mitogen activated protein (MAP) kinases (MAPK), extracellular-signalregulated kinase $1\left(\mathrm{ERK}_{1}\right)$ and kinase $2\left(\mathrm{ERK}_{2}\right)$ [11]. Stimulation of the IGF-I receptor leads to activation of MAP-kinase (p38). IGF-I receptor signaling involves the same proteins and kinases as the $\beta_{1}$-integrin transduction pathway, except for the participation of FAK kinase and Src protein [12]. On the other hand IGF-I receptor stimulate signals through the phosphatidylinositol 3-kinase/Akt pathway. Akt has involved in cell survival via inhibition of pro-apoptotic proteins $[13,14]$ and activation of anti-apoptotic proteins [15].

Berenil (1,3-bis(4'-amidinophenyl)triazene) can exhibit intercalative, as well as minor groove binding, properties when it binds to both DNA and RNA duplexes, while also exhibiting a preference for DNA duplexes with unobstructed minor grooves [16,17]. Recent work on the targeting of antitumor agents to DNA by the use of DNA minor groove-binding ligands has shown that this strategy can greatly enhance both the in vitro cytotoxicity and the in vivo antitumor activity of the alkylating moiety, when compared with untargeted compounds of similar reactivity [18-20].

\section{Materials and methods}

Materials. The compounds Pt1-Pt4 (Fig. 1) have been prepared and described previously [7]. Stock culture of breast cancer MCF7 was purchased from the American Type Culture Collection, Rockville, MD (USA). Dulbecco's minimal essential medium (DMEM) and foetal bovine serum (FBS) used in cell culture were products of Gibco (USA). Glutamine, penicillin and streptomycin were obtained from Quality Biologicals Inc. (USA). Anti-Mouse immunoglobulin antibody, anti-Rabbit immunoglobulin antibody, aprotinin, bacterial collagenase, 5-bromo-4-chloro-3-indolyl phosphate/nitro blue tetrazolium liquid substrate reagent (BCIP/NBT), leupeptin, mouse anti-posphorylated MAPK $\left(\mathrm{ERK}_{1}\right.$ and $\left.\mathrm{ERK}_{2}\right)$ antibody, Nonidet P-40, rabbit anti-phospho-protein kinase $\mathrm{B}$ (Akt), phenylmethylsulfonyl fluoride, acridine orange, ethidium bromide and Protein A-Sepharose were provided by Sigma Chemical Co (USA), as were most other chemicals and buffers used. Nitrocellulose membrane $(0.2 \mu \mathrm{m})$, sodium dodecylsulfate (SDS), polyacrylamide, molecular weight standards and Coomassie Brilliant Blue R-250 were received from Bio-Rad Laboratories (USA). 5-[3 $\left.{ }^{3} \mathrm{H}\right]$-proline $(28 \mathrm{Ci} / \mathrm{mmol})$ was purchased from Amersham (UK). Mouse anti- $\beta_{1}$-integrin antibody, rabbit IGF-IR $\alpha$, rabbit antiNFKB were obtained from Santa Cruz Biotechnology (USA). Rabbit anti-phospho-p38 MAP kinase antibody was purchased from Cell Signaling. Apoptest was a product of DakoCytomation (Denmark). Scintillation coctail "Ultima Gold XR" from Packard (USA).

Cell culture. Human breast cancer MCF-7 cells were maintained in DMEM supplemented with $10 \%$ fetal bovine serum (FBS), $50 \mathrm{U} / \mathrm{ml}$ penicillin, $50 \mu \mathrm{g} / \mathrm{ml}$ streptomycin at $37^{\circ} \mathrm{C}$. Cells were cultured in Costar flasks and subconfluent cells were detached with $0.05 \%$ trypsin and $0.02 \%$ EDTA in calcium-free phosphate buffered saline, counted in hemocytometers and plated at $5 \times 10^{5}$ cells per well of 6-well plates (Nunc) in $2 \mathrm{ml}$ of growth medium (DMEM without phenol red with $10 \%$ CPSR 1 ). Cells reached about $80 \%$ of confluency at day 3 and in most cases such cells were used for the assays.

Collagen production. Incorporation of radioactive precursor into proteins was measured after labeling of the cells in growth medium with varying concentrations of Pt1-Pt4 or cisplatin for $24 \mathrm{~h}$ with $5-\left[{ }^{3} \mathrm{H}\right]$ proline $(5 \mu \mathrm{Ci} / \mathrm{ml}, 28 \mathrm{Ci} / \mathrm{mmol})$ as described previously [21]. Incorporation of tracer into collagen was determined by digesting proteins with purified Clostridium histolyticum collagenase, according to the method of Peterkofsky [22]. Results are shown as combined values for cell plus medium fractions.

Immunoprecipitation. Subconfluent cells in 6-well plates were rinsed with phosphate-buffered saline, scraped out of the wells and centrifuged at $1000 \times \mathrm{g}$ for 3 minutes. Then the cells (from 6 wells) were solubilized with lysis buffer containing $10 \mathrm{mM}$ Tris- $\mathrm{HCl}, \mathrm{pH}$ 7.4, $250 \mathrm{mM} \mathrm{NaCl}, 0.5 \%$ Nonidet P-40, $1 \mathrm{mM}$ EDTA, $1 \mu \mathrm{g} / \mathrm{ml}$ leupeptin, $1 \mu \mathrm{g} / \mathrm{ml}$ aprotinin, $1 \mathrm{mM}$ phenylmethylsulfonyl fluoride, at $4^{\circ} \mathrm{C}$ for 10 minutes. The insoluble material was removed by centrifugation at $10,000 \times \mathrm{g}$ for 5 minutes at $4^{\circ} \mathrm{C}$. Supernatant containing $100 \mu \mathrm{g}$ of protein was added to $100 \mu \mathrm{g}$ of Protein ASepharose that had been linked to primary antibody in the following manner. Protein A-Sepharose was washed 3 times with lysis buffer and $100 \mu \mathrm{l}$ of suspension containing about $100 \mu \mathrm{g}$ of beads was incubated for 1 hour at $4^{\circ} \mathrm{C}$ with $20 \mu \mathrm{l}$ of primary antibody. Then, the conjugate was incubated for 1 hour at $4^{\circ} \mathrm{C}$ with shaking. Immunoprecipitate was washed four times with lysis buffer. Proteins were released from the beads by boiling in SDS sample buffer and loaded onto a 10\% SDS-polyacrylamide gel. The immunoprecipitates were analyzed by Western immunoblot.

SDS-PAGE. Slab SDS/PAGE was used according to the method of Laemmli [23].

Western immunoblot analysis. After SDS-PAGE, the gels were allowed to equilibrate for $5 \mathrm{~min}$. in $25 \mathrm{mmol} / \mathrm{l}$ Tris- $\mathrm{HCl}, 0.2 \mathrm{~mol} / \mathrm{l}$ glycine in $20 \%(\mathrm{v} / \mathrm{v})$ methanol. The protein was transferred to $0.2-$ $\mu \mathrm{m}$ pore-sized nitrocellulose at $100 \mathrm{~mA}$ for 1 hour by using a LKB 2117 Multiphor II electrophoresis unit. The nitrocellulose was incubated with polyclonal antibody against human prolidase at concentration 1:3000, monoclonal antibody against IGF-I receptor at concentration 1:500, monoclonal antibody against $\beta_{1}$-integrin subunit, 


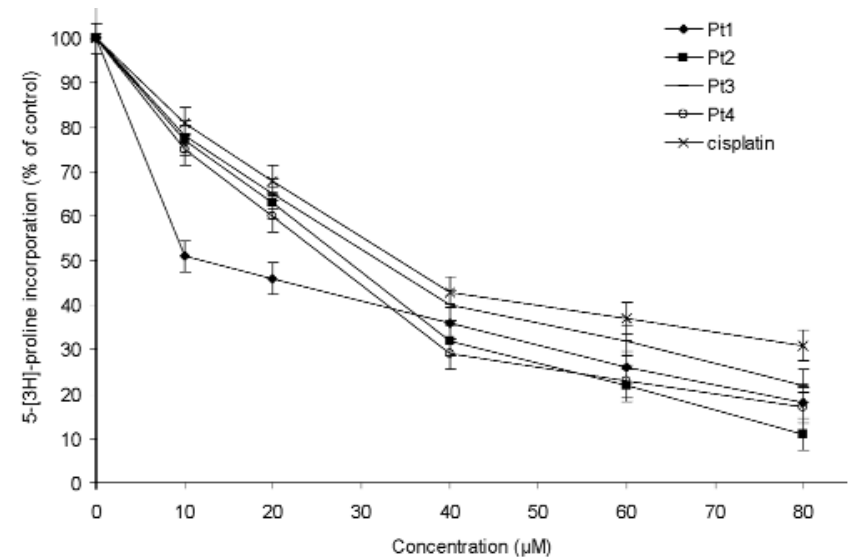

Fig. 2. Collagen synthesis, measured by $5-\left[{ }^{3} \mathrm{H}\right]$-proline incorporation into proteins susceptible to the action of bacterial collagenase, in breast cancer MCF-7 cells cultured for $24 \mathrm{~h}$ in the presence of different concentration of Pt1-Pt4 and cisplatin. Mean values from three independent experiments done in duplicates \pm standard deviation (SD) are presented.

and phosphorylated MAPK at concentration 1:5000 in 5\% dried milk in Tris buffered saline with Tween 20 (TBS-T) $(20 \mathrm{mmol} / \mathrm{l}$ Tris$\mathrm{HCl}$ buffer, $\mathrm{pH} 7.4$, containing $150 \mathrm{mmol} / 1 \mathrm{NaCl}$ and $0.05 \%$ Tween 20) for $1 \mathrm{~h}$. In order to analyze the $\beta_{1}$-integrin subunit and phosphorylated MAP- kinases second antibody-alkaline phosphatase conjugated anti-Mouse immunoglobulin (whole molecule) was added at concentration 1:7500; and in order to analyze IGF-I receptor second antibody-alkaline phosphatase conjugated anti-Goat immunoglobulin (whole molecule) was added at concentration 1:5000. All antbodies were diluted in TBS-T and incubated for $60 \mathrm{~min}$ under gentle shaking. Then nitrocellulose was washed with TBS-T $(5 \times 5 \mathrm{~min})$ and submitted to Sigma-Fast BCIP/NBT reagent.

Flow Cytometry Assessment of Annexin V Binding. Apoptosis was determined by assessment of phosphatidylserine exposure by Annexin V-FITC binding using the Annexin V-FITC staining kit (Apoptest-FITC) according to the manufacturer's instruction. Ungated cells $(10000)$ were analyzed in a flow cytometer (Beckman Coulter, Fullerton, CA, USA). Annexin V binds with high affinity to phosphatidylserine and can thus be used to identify cells in all stages of programmed cell death [24,25]. Propidium iodide exclusively stains cells with a disrupted cell membrane and can be used to identify late apoptotic and dead cells.

Fluorescent Microscopy Assay. To asses apoptosis, cell viability was estimated 24 hours after the addition of the examined compounds. The cell suspension $(250 \mu \mathrm{l})$ was stained with $10 \mu \mathrm{l}$ of the dye mixture ( $10 \mu \mathrm{M}$ acridine orange and $10 \mu \mathrm{M}$ ethidium bromide), which was prepared in PBS. Acridine orange (fluorescent DNAbinding dye) intercalates into DNA, making it appear green, and binds to RNA, staining it red/orange. Ethidium bromide is only taken up by nonviable cells; its fluorescence overwhelms that of the acridine orange, making the chromatin of necrotic cells appear orange [26]. Two hundred cells per sample were examined by fluorescence microscopy, according to the following criteria: viable cells with normal nuclei (fine reticular pattern of green stain in the nucleus and red/orange granules in the cytoplasm); viable cells with apoptotic nuclei (green chromatin which is highly condensed or fragmented and uniformly stained by the acridine orange); nonviable cells with normal nuclei (bright orange chromatin with organized structure); and nonviable cells with apoptotic nuclei (bright orange chromatin which is highly condensed or fragmented).
Statistical analysis. In all experiments, the mean values for three assays \pm standard deviations (SD) were calculated. The results were submitted to statistical analysis using the Student's t-test. Differences were considered as a significant at $p<0.05$. Mean values, the standard deviations and the number of measurements in the group (n) are presented in the figures. These statistical analyses were carried out using Origin 7.5 software (OriginLab, USA).

\section{Results}

Collagen biosynthesis was measured in MCF-7 breast cancer cells treated with various concentrations of compounds Pt1-Pt4 and cisplatin for 24 hours. As shown on Fig. 2 Pt1-Pt4 were found to be more effective inhibitor of collagen biosynthesis than cisplatin. The inhibitory effect was dose dependent. In terms of reduction of collagen biosynthesis, the compounds rank MCF-7 cells in the order Pt1 $>$ Pt $4>$ Pt $2>$ Pt $3>$ cisplatin. The values of $\mathrm{IC}_{50}$ were relatively higher for $\mathrm{Pt} 1$ and Pt4 which possess piperazine and isopropylamine ligands around the Pt center, respectively.

Collagen biosynthesis is regulated by the signal mediated by activated $\beta_{1}$-integrin receptors [8]. The expression of the receptor in MCF-7 cell lines was measured by western immunoblot. As shown on Fig. 3 treatment of the cells with $20 \mu \mathrm{M}$ of Pt1-Pt4 evoked more stimulatory effect than $20 \mu \mathrm{M}$ of cisplatin on the protein expression in MCF-7 cell lines. Collagen biosynthesis is also known to be regulated by IGF-I receptor. IGF-I, acting predominantly through the IGF-I receptor [8]. The expression of the receptor was increased in MCF-7 cancer cell lines treated with $20 \mu \mathrm{M}$ Pt1-Pt4 and $20 \mu \mathrm{M}$ of cisplatin for $24 \mathrm{~h}$ (Fig. 3). Up regulation of the receptor was more pronounced by Pt4 (Fig. 3).

The MAP-kinase (ERK1/2, p38) pathway induced by activated $\beta_{1}$-integrin and IGF-I receptors is considered to play a central role in carcinogenesis and tumor progression. IGF-I receptor signaling involves the same proteins and kinases as the $\beta_{1}$-integrin transduction pathway, except for the participation of FAK kinase and Src protein [12]. As shown on Fig. 3 treatment of MCF-7 cell lines with $20 \mu \mathrm{M}$ cisplatin and Pt1-Pt4 for 24 hours increased the expression of phosphorylated MAP-kinases ERK1/2 and p38.

IGF-I receptors stimulates signals through the phosphatidylinositol 3-kinase/Akt pathway which regulate survival via inhibition of pro-apoptotic proteins $[13,14]$ and activation of anti-apoptotic proteins [15]. Interestingly, in our experiments increase expression of IGF-I receptors stimulated through cisplatin and Pt1-Pt4, evoke decrease on the expression of phospho Akt (Fig. 3). Stimulation of the $\beta_{1}$ integrin and IGF-I receptors leads to induction of MAP-kinase (ERK1/2, p38) pathway, which induced transcription factors. We have found that in the presence of Pt1-Pt4 drastically increased expression of NF- $\kappa \mathrm{B}$, well known transcriptional inhibitor of collagen gene expression (Fig. 3). 


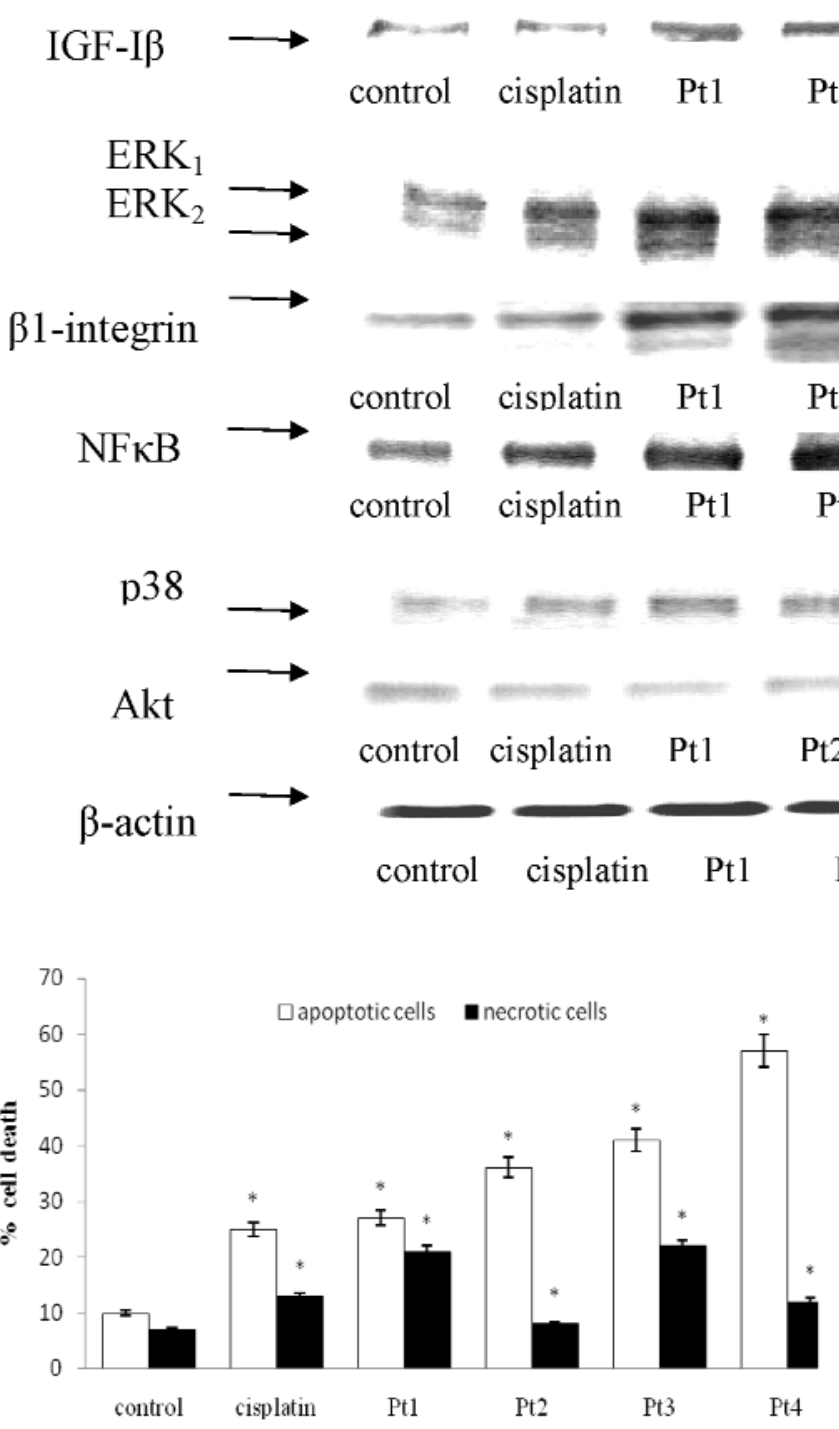

Fig. 4. Morphological apoptosis evaluation in the annexin V-FITC assay on MCF-7 breast cancer cells treated $24 \mathrm{hr}$ with $20 \mu \mathrm{M}$ of Pt1-Pt4 and cisplatin. White columns represent Annexin'/Propidium iodide- cells in the apoptotic stage and black columns represent Annexin $^{+} /$Propidium iodide ${ }^{+}$cells in the necrotic stage. Mean percent \pm SD from three independent experiments are presented. *Significantly different from control $(\mathrm{p}<0.05)$.

Flow cytometric analyses based on the detection of morphological changes, DNA fragmentation, DNA loss, and membrane changes are increasingly used for quantitative investigations of apoptosis. To determine the nature of cell death induced by Pt1-Pt4 and cisplatin in human MCF-7 breast cancer cells, we measured cell death by flow cytometric analysis after annexin V-FITC and propidium iodide staining. During the early stage of apoptosis, phosphatidylserine translocates from the interior to the exterior part of the plasma membrane and becomes exposed at the cell surface, facilitating recognition by macrophages $[24,25]$. Annexin V binds with high affinity to phos-

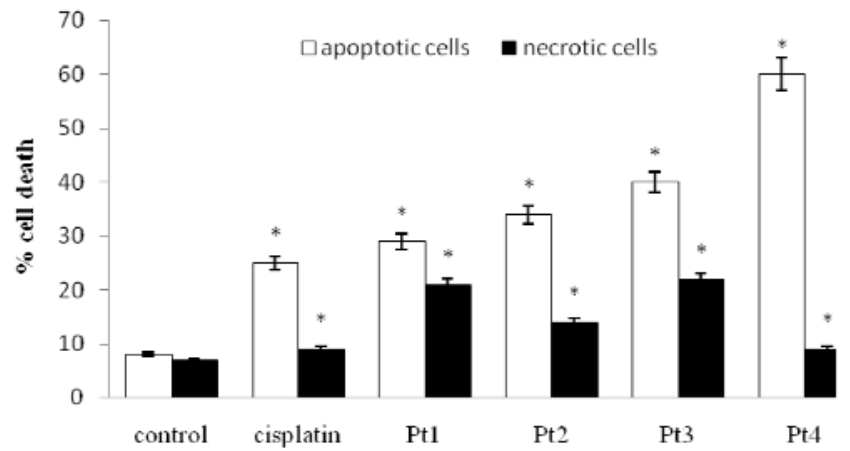

Fig. 5. Induction of apoptosis in MCF-7 breast cancer cells treated for $24 \mathrm{hr}$ with $20 \mu \mathrm{M}$ of Pt1-Pt4 and cisplatin evaluated by a fluorescent microscopy assay after acridine orange and ethidium bromide staining. Mean percent \pm SD from three independent experiments are presented. Apoptotic and necrotic cells were differentiated according to the criteria described in Materials and methods. *Significantly different from control $(\mathrm{p}<0.05)$.

phatidylserine and can thus be used to identify cells in all stages of programmed cell death. Propidium iodide exclusively stains cells with a disrupted cell membrane and can be used to identify late apoptosis and dead cells. We have found that the apoptotic effect of Pt1$\mathrm{Pt} 4$ was time-dependent and definitely stronger than evoked by cisplatin. We also demonstrated that Pt1-Pt4 and cisplatin caused increase necrotic cell death. At the high concentration of $100 \mathrm{nM}$, cell was attributable to both an increase in number of apoptotic (Annexin ${ }^{+}$ /Propidium iodide-) and necrotic (Annexin ${ }^{+} /$Propidium iodide $^{+}$) cells (Fig. 4). Pt1-Pt4 and cisplatin triggered apoptosis in MCF-7 breast cancer cells was also 
estimated by a fluorescent microscopy assay after acridine orange and ethidium bromide staining (Fig. 5). The percentage of early apoptotic cells was similar to the percentage of Annexin V-FITC. It was shown that all of analyzed compounds inhibited the proliferation of cells in the malignant cell lines mainly by increasing the number of apoptotic cells.

\section{Discussion}

One of the characteristic features of breast cancer cells is a deregulation of their interaction with extracellular matrix proteins [27]. Collagen is the most abundant component of extracellular matrix and is responsible for the maintenance of the architecture and the integrity of connective tissue. It is known that the interaction between integrin receptors and extracellular matrix proteins, e.g. collagen, can regulate neoplastic cell attachment, migration, proliferation, progression and survival [28]. Therefore changes in the quantity, structure and distribution of collagens caused by anticancer agents may affect human breast cancer cells metabolism and function [29]. We showed that Pt1-Pt4 are stronger inhibitors of collagen biosynthesis than cisplatin. Decreased amount of collagen in extracellular matrix is known to enhance motility and invasion of neoplastic cells [30], but it also contribute to inhibition of cell growth and induction of apoptosis [31]. We found that up regulation of the expression of $\beta_{1}$-integrin and IGF I receptor by Pt1-Pt4 was accompanied by increase in the expression of MAP-kinases in MCF7 cell lines. The result of this phenomenon is induction of transcription factors and stimulation of the expression of genes for integrins, metalloproteinases, proteases and many other proteins involved in the regulation of protein biosynthesis, cell growth and differentiation [32]. Also IGF-I receptor stimulate signals through the phosphatidylinositol 3-kinase/Akt pathway. Akt has involved in cell survival via inhibition of pro-apoptotic proteins $[13,14]$ and activation of antiapoptotic proteins [15].

In this study we have found that Pt1-Pt4 modulate collagen biosynthesis in breast cancer cells. The inhibition was found to be dependent on the $\beta_{1}$ integrin and IGF receptor activation. The end-point of the cross-talk between both receptors was situated at the MAPK signaling and level of NF-KB. In the presence of Pt1-Pt4 effected to stimulate expression of NF- $\kappa B$, while it stimulated expression of p-38 and ERK1/ERK2 but not Akt. Both stimulation of NF- $\mathrm{BB}$ and inhibition of Akt contributed to down regulation of collagen production. NF- $\mathrm{KB}$ is known to be involved in inhibition of collagen gene transcription through binding to both $\alpha_{1}$ and $\alpha_{2}$ collagen promoter [33-35].

$\mathrm{NF}-\kappa \mathrm{B}$ as transcription factor may also regulate apoptosis, cell proliferation, cell growth arrest, as well as angiogenesis via stimulation of vascular endothelial growth factor expression [36]. On the other hand Akt is known as a signaling inductor of cell survival acting through up-regulation of anti-apoptotic proteins. Combination of increase of the expression of NF- $\mathrm{KB}$ and decrease of the expression of Akt may leads to increase apoptosis.

Activation of IGF-I receptor plays important role in cellular transformation, mitogenesis and inhibition of apoptosis. Our experiments made with annexin V-FITC and detection of apoptosis by a fluorescent microscopy assay revealed that Pt1-Pt4 inhibited the proliferation of MCF-7 malignant cells by increasing the number of apoptotic and necrotic cells. The apoptotic effect of cisplatin was significantly weaker. The presented data suggest that Pt1-Pt4 impair more efficiently growth and metabolism of MCF-7 breast cancer cells than cisplatin. Therefore, these complexes represent a new class of anti-cancer agents, distinct in DNA binding and anti-tumour activity compared to cisplatin and are of special interest since the molecular interactions they are capable of are not possible for their mononuclear counterpart. Further investigations on the mechanism of the cytotoxicity of Pt1-Pt4 are now in progress and they will be described in due course.

\section{References}

[1] Brabec V, Kasparkova J. Modifications of DNA by platinum complexes: Relation to resistance of tumors to platinum antitumor drugs. Drug Resist Updates. 2005;8:131-146.

[2] Wong E, Giandomenico CM. Current Status of PlatinumBased Antitumor Drugs. Chem Rev. 1999;99:2451-2466.

[3] Rosenberg B, Camp L, Trosko JE. Mansour VH. Platinum compounds: a new class of potent antitumor agents. Nature. 1996;222:385-386.

[4] Mukhopadhyay R, Dubey P, Sarkar S. Structural changes of DNA induced by mono- and binuclear cancer drugs. $J$ Struct Biol. 2005;150:277-283.

[5] Kasparkova J, Vrana O, Farrell N, Brabec V. Effect of the geometry of the central coordination sphere in antitumor trinuclear platinum complexes on DNA binding. J Inorg Biochem. 2004;98:1560-1569.

[6] Bielawski K, Bielawska A, Słodownik T, Popławska B, Bołkun-Skórnicka U. DNA-binding activity and cytotoxicity of Pt-berenil compounds in MDA-MB-231 and MCF-7 breast cancer cells. Acta Pol Pharm Drug Res. 2008;65:135-140.

[7] Bielawski K, Bielawska A, Popławska B, Bołkun-Skórnicka U. Synthesis, DNA-binding affinity and cytotoxicity of the dinuclear platinum(II) complexes with berenil and amines ligands. Acta Pol Pharm Drug Res. 2008;65:363-370.

[8] Goldstein RH, Poliks CF, Plich PF, Smith BD, Fine A. Stimulation of collagen formation by insulin-like growth factor-I in cultures of human lung fibroblasts. Endocrinology. 1989;124:964-970.

[9] Hanks SK, Calalb MB, Harper MC, Patel SK. Focal adhesion protein-tyrosine kinase phosphotylated in response to cell attachment to fibronectin. Proc Natl Acad Sci USA. 1992;89:8487-91.

[10] Juliano R. Cooperation between soluble factors and integrinmediated cell anchorage in the control of cell growth and differentiation. Bioessays. 1996;18:911-7. 
[11] Seger R, Krebs EG. The MAPK signaling cascade. FASEB $J$. 1995;9:726-35.

[12] Butler AA, Shoshana Y, Gewolb IH, Karas M, Okubo Y, LeRoith D. Insulin-like growth factor-I receptor signal transduction: at the interface between physiology and cell biology. Comp Biochem Physiol B. 1998;121:19-26.

[13] Cardone MH, Roy N, Stennicke HR, Salvesen GS, Franke TF, Stanbridge E, Frisch S, Reed GC. Regulation of cell death protease caspase-9 by phosphorylation. Science. 1998;282: 1318-1321.

[14] Datta SR, Dudek HTX, Tao X, Masters S, Fu H, Gotoh Y, Greenberg ME. Akt phosphorylation of BAD couples survival signals to the cell-intrinsic death machinery. Cell. 1997;91:231-241.

[15] Pugazhenthi S, Nesterova A, Sable C, Heidenreich KA, Boxer LM, Heasley LE, Reusch JE. Akt/protein kinase B up-regulates Bcl-2 expression through cAMP-response element-binding protein. $J$ Biol Chem. 2000;10761-66.

[16] Barcelo F, Ortiz-Lombardia M, Portugal J. Heterogeneous DNA binding modes of berenil. Biochim Biophys Acta. 2001;1519:175-184.

[17] Nguyen B, Hamelberg D, Bailly Ch, Colson P, Stanek J, Brun R, Neidle S, Wilson WD. Characterization of a novel DNA minor-groove complex. Biophys J. 2004;86: 1028-1041.

[18] Denny WA. DNA minor groove alkylating agents. Curr Med Chem. 2001;8:533-44.

[19] Bartulewicz D, Bielawski K, Bielawska A, Różański A. Synthesis, molecular modelling, and antiproliferative and cytotoxic effects of carbocyclic derivatives of distamycin with chlorambucil moiety. Eur J Med Chem. 2001;36:461-7.

[20] Bielawska A, Bielawski K, Wołczyński S, Anchim T. Structure-Activity studies of novel amidine analogues of chlorambucil: correlation of cytotoxic activity with DNA-binding and topoisomerase II inhibition. Arch Pharm Med Chem. 2003; 336:293-9.

[21] Oyamada I, Pałka J, Schalk EM, Takeda K, Peterkofsky B. Scorbutic and fasted guinea pig sera contain an insulin-like growth factor I reversible inhibitor of proteoglycan and collagen synthesis in chick embryo chondrocytes and adult human skin fibroblasts. Arch Biochem Biophys. 1990;276:85-93.

[22] Peterkofsky B, Pałka J, Wilson S, Takeda K, Shah V. Elevated activity of low molecular weight insulin-like growth factor-binding proteins in sera of vitamin C-deficient and fasted guinea pigs. Endocrinology. 1991;128:1769-79.

[23] Laemmli UK. Cleavage of structural proteins during the assembly of the head of bacteriophage T4. Nature. 1970; 227:680-5.

[24] Martin SJ, Reutelingsperger CP, McGahon, AJ, Rader JA, van Schie RC, LaFace DM, Green DR. Early redistribution of plasma membrane phosphatidylserine is a general feature of apoptosis regardless of the initiating stimulus: inhibition by overexpression of Bcl-2 and Abl. J Exp Med. 1995;182:15451556.

[25] Vermes I, Haanen C, Steffens-Nakken H, Reutelingsperger C. A novel assay for apoptosis. Flow cytometric detection of phosphatidylserine expression on early apoptotic cells using fluorescein labelled Annexin V. J Immunol Methods. 1995; 184: 39-51.

[26] Cohen JJ, Duke RC, Fadok VA, Sellins KS. Apoptosis and programmed cell death in immunity. Annu Rev Immunol. 1992;10:267-293

[27] Boudreau N, Bissel MJ. Extracellular matrix signaling: integration of form and function in normal and malignant cells. Curr Opin Cell Biol. 1998;10:640-6.

[28] Albeda SM, Buck CA. Integrins and other cell adhesion molecules. FASEB J. 1990;4:2868-80.

[29] Ioachim E, Charchanti A, Briasoulis E, Karavasilis V, Tsanou $\mathrm{H}$, Arvanitis DL. Immunohistochemical expression of extracellular matrix components tenascin, fibronectin, collagen type IV and laminin in breast cancer: their prognostic value and role in tumour invasion and progression. Eur J Cancer. 2002;38: 2362-70.

[30] Perumpanani, AJ, Byrne HM. Extracellular matrix concentration exerts selection pressure on invasive cells. Eur J Cancer. 1999;35:1274-80

[31] Boudreau N, Sympson CJ, Werb Z, Bissel M. Suppression of ICE and apoptosis in mammary epithelial cells by extracellular matrix. Science. 1995;267:891-3.

[32] Labat-Robert J, Robert L. Interaction between cells and extracellular matrix: signaling by integrins and the elastin-laminin receptor. Prog Mol Subcell Biol. 2000;25:57-70.

[33] Kouba DJ, Chung KY, Nishiyama T, Vindevoghel L, Kon A, Klement JF, Uitto J, Mauviel A. Nuclear factor-kappa B mediates TNF-alpha inhibitory effect on alpha 2(I) collagen (COL1A2) gene transcription in human dermal fibroblasts. J Immunol. 1999;162:4226-34.

[34] Rippe RA, Schrum LW, Stefanovic B, Soli's-Herruzo JA, Brenner DA. NF-kappaB inhibits expression of the alpha1(I) collagen gene. DNA Cell Biol. 1999;18:751-61.

[35] Miltyk W, Karna E, Palka JA. Prolidase-independent mechanizm of camptothecin-induced inhibition of collagen biosynthesis in cultured human skin fibroblasts. $J$ Biochem. 2007;141:287-292.

[36] Kumar A, Takada Y, Boriek AM, Aggarwal BB. Nuclear factor- $\mathrm{KB}$ : its role in health and disease. $J$ Mol Med. 2004; $82: 434-48$. 